\title{
Lights, camera, action!: Using cinematographic genre in English language classes
}

\author{
Lights, camera, action!: Uso do gênero cinematográfico no ensino de língua inglesa \\ Lights, camera, action!: Uso del género cinematográfico en la enseñanza del lenguaje inglés
}

Received: 10/03/2021 | Reviewed: 10/09/2021 | Accept: 10/15/2021| Published: 10/17/2021

Eristóteles Pegado Andrade

ORCID: https://orcid.org/0000-0003-2741-1558 Instituto Federal de Educação, Ciência e Tecnologia do Piauí, Brazil E-mail: pegadothe@gmail.com

Amilcar Ximenes de Albuquerque Junior

ORCID: https://orcid.org/0000-0002-9649-0520 Instituto Federal de Educação, Ciência e Tecnologia do Piauí, Brazil E-mail: amilcar.albuquerque@ifpi.edu.br

Márcio Aurélio Carvalho de Morais

ORCID: https://orcid.org/0000-0001-6626-1615 Instituto Federal de Educação, Ciência e Tecnologia do Piauí, Brazil E-mail: marcio@ifpi.edu.br

\begin{abstract}
This study consists of an academic activity carried out in a master's degree in Professional and Technological Education (PROFEPT) of Instituto Federal do Piauí (IFPI) in progress. The use of the short film genre in English language teaching becomes relevant as it allows the student the opportunity to practice and understand the language orally and critically. In this context, this article sought in the epistemological way to discuss the dyad education and work and their conceptions and interrelationships in professional and technological education, as well as to present a prior state of the art on the use of short films in the English language teaching in technology in contemporary society. From a qualitative perspective, this systematic literature review used as references: journals, dissertations, theses and books, found through the following databases: SciELO, Portal Capes and Google Scholar. Therefore, due to the aspects mentioned in this academic-scientific investigation, it was possible to show that the short film genre is a pedagogical strategy to promote the praxis of conversation in English language classes with students in the High School Technical Professional Education, considering contextualization and interdisciplinarity as guiding principles, thus ensuring the inseparability between theory and social practice. This research seeks to highlight the conceptions, possibilities and challenges in contemporary English language teaching, through the short film genre.
\end{abstract}

Keywords: Professional and technological education; Short film; Art and culture; English language.

\section{Resumo}

Este estudo consiste numa atividade acadêmica realizada no Mestrado em Educação Profissional e tecnológica (PROFEPT) do Instituto Federal do Piauí (IFPI) em andamento. O uso de gênero cinematográfico curta-metragem no ensino da língua inglesa torna-se relevante pois possibilita ao estudante a oportunidade de praticar e compreender o idioma de forma oral e de maneira crítica. Diante desse contexto, com o presente artigo buscou-se no campo epistemológico discorrer acerca da díade educação e trabalho e suas concepções e inter-relações na educação profissional e tecnológica, bem como apresentar um estado da arte prévio sobre o uso de curta-metragem no ensino de língua inglesa na tecnologia na sociedade contemporânea. De caráter qualitativo esta revisão sistemática da literatura utilizou como referências: periódicos, dissertações, teses e livros, levantadas por meio das bases de dados: SciELO, Portal Capes e Google Scholar. Portanto, em virtude dos aspectos abordados nessa investigação acadêmicacientífica foi possível evidenciar que o gênero cinematográfico curta-metragem é uma estratégia pedagógica de fomento das práxis da conversação nas aulas de língua inglesa na formação dos discentes da Educação Profissional Técnica de Nível Médio, considerando como princípios norteadores a contextualização e interdisciplinaridade, dessa maneira, garantindo a indissociabilidade entre a teoria e a prática social. Essa pesquisa evidenciou as concepções, possibilidades e desafios no ensino de língua inglesa na contemporaneidade, através do gênero cinematográfico curtametragem.

Palavras-chave: Educação profissional e tecnológica; Curta-metragem; Arte e cultura; Língua inglesa.

\section{Resumen}

Este estudio consiste en una actividad académica realizada en la Maestría en Educación Profesional y Tecnológica (PROFEPT) del Instituto Federal de Piauí (IFPI) en curso. El uso del género del cortometraje en la enseñanza del idioma inglés se vuelve relevante ya que le brinda al estudiante la oportunidad de practicar y comprender el idioma de manera oral y crítica. Ante este contexto, este artículo buscó en el campo epistemológico discutir la educación y el 
trabajo de la díada y sus concepciones e interrelaciones en la educación profesional y tecnológica, así como presentar un estado del arte previo sobre el uso del cortometraje en la enseñanza del idioma inglés en tecnología en la sociedad contemporánea. Con carácter cualitativo, esta revisión sistemática de la literatura utilizó como referencias: revistas, disertaciones, tesis y libros, levantados a través de las siguientes bases de datos: SciELO, Portal Capes y Google Scholar. Por lo tanto, debido a los aspectos abordados en esta investigación académico-científica, se pudo evidenciar que el género del cortometraje es una estrategia pedagógica para promover la praxis de la conversación en las clases de idioma inglés en la formación de estudiantes de Educación Técnica Profesional de Nivel Medio, considerando la contextualización y la interdisciplinariedad como principios rectores, asegurando así la inseparabilidad entre teoría y práctica social. Esta investigación destacó las concepciones, posibilidades y desafíos en la enseñanza del idioma inglés contemporáneo, a través del género del cortometraje.

Palabras clave: Educación profesional y tecnológica; Cortometraje; Arte y Cultura; Idioma en inglés.

\section{Introduction}

The English language, being one of the most widely spoken languages in the world, is a very important mediating instrument for communication in the globalized world, as well as being a factor of social inclusion. It seeks to bring opportunities and enable the English-speaking student to become a much more attractive person for the job market as well for the best universities in the world. In this context, the Base Nacional Comum Curricular (2017, p. 477) emphasizes that:

As aprendizagens em inglês permitirão aos estudantes usar essa língua para aprofundar a compreensão sobre o mundo em que vivem, explorar novas perspectivas de pesquisa e obtenção de informações, expor ideias e valores, argumentar, lidar com conflitos de opinião e com a crítica, entre outras ações relacionadas ao seu desenvolvimento cognitivo, linguístico, cultural e social. Desse modo, eles ampliam sua capacidade discursiva e de reflexão em diferentes áreas do conhecimento.

Based on this reality, there is a need to develop activities in which digital technologies are used, in order to involve students in the assimilation of new knowledge, which can help in the teaching-learning process of the English language. This work is important for English language teachers to assist in the student's development, using the short film genre as a support so that participants can interact, interpret everyday situations, inducing participants to have a conversation in English. About the topic short film genre Moletta (2009, p.17) stands out that:

[...] trata-se de uma forma breve e intensa de contar uma história ou expor um personagem [...]. Esse formato de cinema tem como principais características a precisão, a coerência, a densidade e a unidade de ação ou impressão parcial de uma experiência humana.

It is also important to point out that this study adds to society by ensuring an improvement in the educational environment, making the classes more attractive and dynamic, allowing the public involved in this activity, the opportunity to practice the language orally, acquiring a better fluency in the exercise of speech, vocabulary memorization, improved pronunciation, in addition to acquiring a vast vocabulary knowledge as well in the making of movie scripts.

This qualitative academic research consists of a systematic literature review. As for the objective, it is a basic research. The following were used as references: periodicals, dissertations, theses and books raised through the databases: SciELO, Portal Capes and Google Scholar.

That said, many research questions can be raised when the objective is to structure an interface of this context with education. Within this framework, therefore, the following research problem is constituted: How the theme "technology in contemporary society" can be discussed in English language classes in High School Technical Course in Informatics, articulated in an integrated way through the short film genre. In view of this context, the following specific objectives are shaped, that is to identify with the teachers in information technology area, which contemporary themes of the Technological Axis Information and Communication can be worked on in English language classes, as well as to investigate with English 
language teachers how work the cinematographic short film genre in High School Technical Professional Education.

Thus, with this review article, we sought in the epistemological field to discuss the dyad education and work and their conceptions and interrelationships in professional and technological education, as well as to present a prior state of the art on the use of the short film genre in English language teaching related to technology in contemporary society.

\section{Methodology}

For the development of this study, bibliographical research in literature that deals with Professional and Technical Education was used as a methodology, as well as presenting a prior state of the art on the use of the cinematographic genre in English language teaching. The use of bibliographic research in education enables the discovery of several perspectives on a theme, obtaining a plurality of understandings that, even if they are dichotomous, will give the researcher a broader view of the object to be investigated (Sampaio \& Mancini, 2007). From this purpose, it is essential in this context to build a theoretical framework that guides the analyzes constitution and reflections about this relationship between Professional and Technological Education and the use of the cinematographic genre in English language teaching. Thus, conducting a bibliographic research (Gil, 2010) is the most appropriate way to promote the considerations that guided this study, thus nourished by contexts related to the arguments inhabited in these two spaces.

The bibliographical research is manifested as the main base consulting in books, periodicals and scientific articles posted in the virtual environment. Among the authors surveyed are Saviani (2003), Pacheco (2015), Marson, Miquelante and Lanferdini (2018) and Gramsci (1982), for example. This is a systematic literature review on the theoretical contribution with themes related to the analysis and relation between Professional and Technical Education with the use of the cinematographic genre in English language teaching. The systematic literature review aims to gather and synthesize pre-existing knowledge on a given topic. It is defined as one in which conclusions from previously conducted studies are summarized in order to formulate inferences about a specific topic. It is a valuable method for research, because this method allows for agility in the dissemination of knowledge and because of the relevance of the applicability of this method to historical research, enabling the synthesis of multiple studies on a given subject, in addition to pointing out knowledge gaps that need to be filled with the completion of new studies (Mendes, Silveira \& Galvão, 2008; Roman \& Friedlander, 1998).

\section{Results and Discussion}

In the epistemological field, we sought to discuss the dyad education and work and its conceptions and interrelationships in professional and technological education, as well as to present a prior state of the art on the use of the cinematographic genre in English language teaching.

\subsection{Education and Work: Conceptions and their interrelationships in Professional and Technological Education}

Emphasizing the dimensions: work, science, technology and culture, as one of the conceptual bases of professional and technological education, it is clear that, historically, work has been associated with education as a means of humanization.

Work is understood as an activity of Man About Nature to transform in benefit of his own existence, as Saviani states (2003, p.133), “[...] ajustar a natureza às necessidades, às finalidades humanas, é o que se faz pelo trabalho. Trabalhar não é outra coisa senão agir sobre a natureza e transformá-la [...]", being a positive factor the individual humanization. According to these considerations, Silva (2020) still emphasizes that the labor is one of the first interactions with the purpose of changing the reality. Additionally, work is a cultural factor and an important tool in the construction of a society's culture, because when we work, we are producing our existence, producing culture. In this relationship between work and culture Nosella (2018 p.44) 
stands out that culture

[...] é organização, disciplina do próprio interior, é tomada de posse de sua própria personalidade, é conquistar uma consciência superior, através da qual consegue-se compreender seu próprio valor histórico, sua própria função na vida, seus direitos e seus deveres.

In addition to this perspective, Vieira Pinto (1985) says that

A cultura é, por conseguinte, coletânea do processo de hominização, não tem data de nascimento definida nem forma distintiva inicial. A criação da cultura e a criação do ser humano são na verdade duas faces de um só processo, que passa de principalmente orgânico na primeira fase a principalmente social na segunda, sem, contudo, em qualquer momento deixarem de estar presentes os dois aspectos e de se condicionarem reciprocamente.

In this author's words, the importance of this cultural process in society is clear, where it is impossible to imagine the construction of the human being without culture, because culture is a fundamental part in the process of building the feature of each individual.

Work, culture, science and technology work together in the construction of the individual's identity, knowledge and human formation, so the professional and technological education institutions emerge with the objective of building a society more humanized. And about this topic, schools that have as an educational focus working on science and technology, Sousa (2019 p.52) finds that "Para além da instrumentalização, a escola emancipatória deverá ser o local de troca de experiências e de diálogo para o fomento da superação das desigualdades sociais”.

Pacheco (2015, p. 25), in his turn, suggests that

A referência fundamental para a educação profissional e tecnológica é o ser humano e, por isso, o trabalho, como categoria estruturante do ser social, é seu elemento constituinte. Trata-se, pois, de uma formação que se dá no decorrer da vida humana, por meio das experiências e conhecimentos, ao longo das relações sociais e produtivas. A educação para o trabalho nessa perspectiva se entende como potencializadora do ser humano, enquanto integralidade, no desenvolvimento de sua capacidade de gerar conhecimentos a partir de uma prática interativa com a realidade, na perspectiva de sua emancipação. Na extensão desse preceito, trata-se de uma educação voltada para a construção de uma sociedade mais democrática, inclusiva e equilibrada social e ambientalmente.

According to the aforementioned author, the human being is always in continuous training through the experiences and knowledge acquired throughout life, with work and education as fundamental factors in this process of social development. Meanwhile, the capacity for knowledge is enhanced through the interactive practices that education for work provides, building a fairer and more egalitarian society with reflective human beings.

Considering the work as an educational principle, Gramsci (1982 p. 130) states that

O princípio educativo sobre o qual se baseavam as escolas elementares era o conceito de trabalho, que não se pode realizar em todo seu poder de expansão e de produtividade sem um conhecimento exato e realista das leis naturais e sem uma ordem legal que regule organicamente a vida recíproca dos homens, ordem que deve ser respeitada por convenção espontânea e não apenas por imposição externa, por necessidade reconhecida e proposta pelos próprios homens como liberdade e não por simples coação.

In this way, article 3, item IV, of the Resolution CNE/CP $n^{\circ}$. 1, of January $5^{\text {th }}$, 2021, which defines the General National Curriculum Guidelines (Diretrizes Curriculares Nacionais Gerais) for Professional and Technological Education has as guiding principles:

Art. $3^{\circ}$ - Centralidade do trabalho assumido como princípio educativo e base para a organização curricular, visando à construção de competências profissionais, em seus objetivos, conteúdos e estratégias de ensino e aprendizagem, na 
perspectiva de sua integração com a ciência, a cultura e a tecnologia.

Pacheco (2015, p 30), has also highlighted the importance of the integrated curriculum in the organization of citizen knowledge as an individual inserted in the production process, and from this point onwards, producing knowledge and better understanding the world around them.

[...] ao se inserir no processo produtivo o homem desenvolve sua compreensão deste e do mundo, produzindo novos conhecimentos. O currículo integrado organiza o conhecimento e desenvolve o processo de ensino-aprendizagem de modo que os conceitos sejam apreendidos como sistema de relações de uma totalidade concreta que se pretende explicar/compreender. (Pacheco 2015, p. 30)

The author also highlights important factors in omnilateral training, as according to Pacheco (2015, p. 29) "a formação humana omnilateral inclui o trabalho, a ciência e a cultura. $\mathrm{O}$ trabalho tem de ser compreendido tanto em seu sentido ontológico, enquanto realização humana, quanto prática econômica associada ao modo de produção."

It is also necessary to consider the importance of polytechnics for the formation of critical citizens within society in view of the difficulties found in production techniques, which require the worker to reinvent himself. In this way a polytechnic education is necessary, as evidenced by Saviani (2003, p. 142):

A ideia de politecnia envolve a articulação entre trabalho intelectual e trabalho manual, implicando uma formação que, a partir do próprio trabalho social, desenvolva a compreensão das bases da organização do trabalho na nossa sociedade e que, portanto, nos permite compreender o seu funcionamento.

In this way, article 3 , item III of the Resolution CNE/CP $n^{\circ} .1$, of January $5^{\text {th }}, 2021$, which defines the General National Curriculum Guidelines (Diretrizes Curriculares Nacionais Gerais) for Professional and Technological Education, brings as one of the guiding principles, and fulfilling its role in the formation of the individual searches the "respeito aos valores estéticos, políticos e éticos da educação nacional, na perspectiva do pleno desenvolvimento da pessoa, seu preparo para o exercício da cidadania e sua qualificação para o trabalho" (Brasil, 2021).

As a result of the considerations detailed above, this scientific article seeks to better understand the relationship between education and work and its commitment to the formation of individuals with the purpose of transforming them into critical citizens.

\subsection{Film Genre and English Language Teaching: A State of the Art}

As a world-spoken and studied language, the modern foreign language, English, has an undeniable relevance both for the labor market and for the academic world. As it is a strong means of communication around the world, providing opportunities in large companies with globally known brands, as well as the best universities abroad, the English language has been increasingly studied.

For these reasons, English language teachers have been looking for different ways to approach the themes and contents proposed in English language teaching, as according to Guareschi (2005, p.33) "se a sociedade está mudando de forma tão rápida a escola não pode esperar, precisa se destacar, conhecer e explorar as preferências e interesses de sua clientela. Incluir a mídia em seu espaço acadêmico é uma forma de fazer o diferencial”.

Thus, English language teaching has accompanied these changes in the way it teaches a second language, highlighting not only reading and writing as parameters for learning a second language, but giving a leading role to oral practice, as Silva and Pinheiro (2017, p. 108), agree that with the communicative practice in English language classes, the student's joy in realizing how much he is evolving in learning is noticeable. 
Silva and Pinheiro (2017, p 105) still emphasize that "quando o aluno permanece em uma sala de aula, sem liberdade de expressar sua opinião e esclarecer suas dúvidas, o seu desenvolvimento não se torna satisfatório para a sua formação intelectual."

Given these facts, different methodologies in teaching the English foreign language have reached space in the globalized world, trying to help the individual's intellectual development. Silva and Dias (2019, p 815), highlight that “Os métodos de ensino de língua estrangeira mudaram ao longo do tempo e de acordo com as necessidades e o perfil da sociedade."

From this perspective, it is necessary to highlight the use of media resources (mobile phone, tablet, laptop, internet, streaming platforms, etc.) which have gained space and importance in the way students learn the English language. Reflecting on this issue, Lopes and Nanemann (2015, p.28998) state that

A pesquisa pode e deve ser um componente muito importante na relação dos alunos com o meio em que vivem, utilizando instrumentos com que já estão acostumados a lidar diariamente (internet, celulares, tablets, computadores, câmeras, entre outros). Logo, é possível afirmar que no ensino através da tecnologia disponível nas escolas, o professor pode e deve se renovar a cada contato com seus alunos, pois a educação necessita ser mediadora de um conhecimento amplo, visando à formação de jovens letrados.

In turn, Marson, Miquelante and Lanferdini (2018, p 267) state that, “[...] por meio do uso das novas tecnologias pode contribuir para o engajamento dos estudantes em práticas de uso da linguagem, tendo em vista a predisposição destes para a realização de atividades que contemplem recursos tecnológicos."

According to the aforementioned authors, the use of technology in practical activities can significantly help students in the process of learning a foreign language. Beside this, Jesus and Lima (2016, p. 82) add the importance of activities that involve interactions, when they emphasize that

Por meio dessas interações, os participantes seriam capazes de trocar, compartilhar e discutir ideias, estimulando diálogos culturais e o reconhecimento de diferenças sociais e políticas ao redor do globo, além de aprender a língua inglesa dentro de práticas sociais de uso da língua.

In these authors' words, interactive activities that involve a significant number of participants can favor the process of acquiring a new language. In agreement, Alzao and Feldman (2017, p.158) find that the use of new technologies and learning strategies involving the seventh art can become a great ally in the process of learning a foreign language, in addition to promoting the culture of a people portraying different times and customs.

Given these considerations, the use of new technologies as allies in the student's cognitive process, as well as learning through media, have achieved great importance in the teaching-learning process, not only for developing knowledge aimed at a specific discipline, but for developing the student's identity and world culture. About this reality, Alzao and Feldman (2017, p 156) approach that

Diante de um mundo cada vez mais globalizado e dinâmico, pode-se perceber que a utilização de filmes como modalidade mostra-se relevante como ferramenta no ensino, por sua função na construção e divulgação de significados, na construção da identidade do sujeito e na propagação de diferentes culturas para todos os continentes do globo terrestre.

And precisely from this understanding, there is a need to develop the teaching of the English language, through the short film genre. Lopes and Nanemann (2015, p.28997) emphasize that the short film genre "[...] possui características próprias, como por exemplo, sua duração. Esse "filme" pode durar de 30 segundos a 30 minutos, além de apresentar poucos personagens e uma história curta.” 
Therefore, we tried to highlight throughout the text, the importance of media tools, as well as the cinematographic genre as a resource in the teaching-learning process of a foreign language, highlighting the relevance of this teaching strategy with the intention of recovering self-esteem, teamwork, stimulate creativity, provide interactivity, enabling survey participants to become more critical and humanitarian citizens.

\section{Final Considerations}

Due to the aspects approached in this academic scientific investigation, it was possible to show that the short film genre is a pedagogical strategy to promote the praxis of conversation in English language classes in the training of students in high school technical professional education, considering as principles guiding contextualization and interdisciplinarity, thus ensuring the inseparability between theory and social practice.

In addition, it is important to emphasize that this didactic pedagogical strategy enables a comprehensive education of students, as well as ensuring the construction of significant skills and competences of the English language in the perspective of its integration with science, culture and technology and in the centrality of work as an educational principle.

Finally, this study highlighted the conceptions, possibilities and challenges of Professional and Technical Education in contemporary times through the use of the short film genre in English language classes.

In this context, it is important to emphasize that the development of short films in the context of High School Technical Professional Education is justified because it is an educational practice that can contribute to the exercise of skills, in particular, the English language, thus as the sociolinguistic and cultural development of students.

As we tried to highlight throughout the text, when we understand culture as a means of communication and social interaction, English language teaching enables students not only to be able to decode linguistic symbols, but also to be communicatively competent, that is, capable of produce language acts appropriate to different communication situations or communicative events. From this perspective, it can be seen that the cultural component is configured as an important element to be worked on in the classroom, as it can be characterized as one of the methodological strategies that aim to make teaching dynamic, social, contextualized and close to students' interests.

\section{References}

Alzao, L. S. A. \& Feldiman, A. K. T. (2018). O filme diary of a wimpy kid no ensino da língua inglesa. A Cor Das Letras (UEFS). $18,154-66$.

Brasil. (2021). Governo Federal. Lei de Diretrizes e Bases da Educação Nacional. 05 de janeiro de 2021. Brasília.

Brasil. (2017). Ministério da Educação. Base Nacional Comum Curricular Ensino Médio.

Gil, A. C. (2010). Como elaborar um projeto de pesquisa. (5a ed.), Ed. Atlas.

Gramsci, A. (1982). Os intelectuais e a organização da cultura. Tradução de Carlos Nelson Coutinho. (4a ed.), Civilização Brasileira.

Guareschi, P. A. (2005) Mídia, Educação e Cidadania: Tudo o que você quer saber sobre a mídia. Vozes.

Jesus, D. M. \& Lima, T. B. (2016) Para além de um discurso do fracasso: os sentidos da aprendizagem de alunos de língua inglesa de uma escola pública. In: Jesus, D. M. \& Carbonieri, D. (orgs.). Práticas de multiletramentos e letramento crítico: outros sentidos para a sala de aula de línguas. Campinas: Pontes. 8198.

Lopes, P. K. \& Nanemann, S. M. A. (2015) O curta-metragem como instrumento de ensino dos direitos humanos nas aulas de língua portuguesa. EDUCERE XII Congresso nacional de educação. PUCPR.

Marson, M. Z., Miquelante, M. A. \& Lanferdini, P. A. F. (2018). Leitura imagética de um curta-metragem: o uso das novas tecnologias no ensino de língua inglesa. ENTRETEXTOS (UEL). 18, 265-87.

Mendes, K. D. S., Silveira, R. C. C. P. \& Galvão, C. (2008) M. Revisão integrativa: método de pesquisa para a incorporação de evidências na saúde e na enfermagem integrative literature. Texto \& Contexto Enferm, 17(4), 758-764.

Moletta, A. (2009) Criação de curta-metragem em Vídeo Digital: Uma proposta para produções de baixo custo. Summus, 142. 
Research, Society and Development, v. 10, n. 13, e414101321352, 2021

(CC BY 4.0) | ISSN 2525-3409 | DOI: http://dx.doi.org/10.33448/rsd-v10i13.21352

Nosella, P. (2018) A escola de Gramsci. (5a ed.), Cortez.

Pacheco, E. (2015) Fundamentos político-pedagógicos dos institutos federais: diretrizes para uma educação profissional e tecnológica transformadora. Ed. do IFRN Natal: IFRN.

Roman A.R. \& Friedlander M.R. (1998) Revisão integrativa de pesquisa aplicada à enfermagem. Cogitare Enferm. 3(2),109-12.

Sampaio, R. F. \& Mancini, M. C. (2007) Estudos de revisão sistemática: um guia para síntese criteriosa da evidência científica. Revista Brasileira de Fisioterapia, 11 (1) 83-89. http://www.scielo.br/pdf/rbfis/v11n1/12.pdf.

Saviani, D. (2003) O choque teórico da Politecnia. Trab. educ. saúde. 1 (1), 131-152.

Silva, C. A. (2020) A reforma da educação profissional de nível médio no Brasil: um debate sobre a pedagogia das competências e o trabalho como princípio educativo. 224 f. Tese (Programa de Pós-Graduação em Educação) - Universidade Nove de Julho, São Paulo.

Silva, D. S. R. \& Pinheiro, R. P. (2017). A viabilidade do uso do lúdico nas aulas de língua inglesa. Revista Sítio Novo. 1, $103-117$.

Silva, V. E. G. \& Dias, S. M. V. (2019-2018) Transposição intersemiótica: o recurso cinematográfico para estimular a leitura em Língua Inglesa. In: XXII Congresso Nacional de Linguística e Filologia, CADERNOS DO CNLF. V.XXII, 3, Textos completos. CiFEFil.

Sousa, D. F. de. (2019) Os sentidos atribuídos ao trabalho e a prática docente em Educação Profissional e Tecnológica. Dissertação (Mestrado Profissional em Educação Profissional e Tecnológica) - Instituto Federal de Educação, Ciência e Tecnologia do Amazonas, Campus Manaus Centro, Manaus.

Vieira, P. A. (1985) Teoria da Cultura. In: Ciência e existência: problemas filosóficos da pesquisa científica. Paz e Terra. 